\title{
THE INVESTIGATION OF THE IMPACT OF INVESTMENT SOURCES FOR SUSTAINABILITY ON COUNTRY'S SUSTAINABLE DEVELOPMENT. A CASE OF BALTIC STATES FOR THE PERIOD 2003-2017
}

\author{
Indrè LAPINSKAITE் $(D$, Patrikas JANULEVIČIUS* \\ Department of Financial Engineering, Faculty of Business Management, \\ Vilnius Gediminas Technical University, Vilnius, Lithuania \\ *E-mail: patrikas.janulevicius@stud.vgtu.lt
}

\begin{abstract}
Purpose - is to analyse the different investment sources for sustainable development of a country and reveal the interaction between investment sources for sustainability and a country's sustainable development.

Research methodology - analysis of scientific sources, collection and systematization of statistical data, a method for sustainable development index calculation, correlation regression analysis.

Findings - each analysed country's progress of sustainable development is expressed as integrated sustainable development index revealed that all analysed countries are gradually increasing their sustainable development results. All three analysed investment sources are strongly affecting countries sustainable development, and stochastic relationship exists between variables.

Research limitations - statistical data with incomplete time series, for which not all the most important sustainable development indicators were selected. The case of three Baltic countries (Lithuania, Latvia, and Estonia) is used for the period 2003-2017. The three main investment sources for sustainable development of a country: assignations of the state budget, EU structural funds, and direct investments, are chosen for the research.

Practical implications - results can be used in calculations for other countries sustainable development and investments interactions. They can be used to evaluate the impact of the different source and contribute to the modelling of their use.

Originality/Value - this article is unique because it reveals the interaction of multiple sustainability sources, in terms of investment sources for sustainability and the results of a country's sustainable development. These sources can be supplemented and adapted to other countries (at least in developed countries EU level).
\end{abstract}

Keywords: sustainability, sustainable development indicators, integrated sustainable development index, assignation of the budget, EU funds, direct investment.

JEL Classification: Q01, Q56, O10, O19, O52.

Conference topic: Contemporary Financial Management.

\section{Introduction}

The concept of sustainable development (SD) was formed on the basis of the United Nations Conference on Environment and Development held in Rio de Janeiro in 1992, where 179 countries attended at the United Nations conference under the topic Environment and Development. The world has moved towards the 21 st century and decided to actively achieve sustainable development by signing the Agenda of "United Nations Millennium Declaration" (2000). In this agenda for the first time were formed eight general goals. In 2015 were formed new Agenda "Transforming our world: the 2030 Agenda for Sustainable Development" with 17 goals (SDG, 2015). From the beginning, the main goal is to achieve a better and more sustainable future for all (General Assembly, 2015) and indicates that every country has to set their main goals to achieve and move forward in general.

In order to achieve the goals, each country has to find possible investment sources for SD implementation and maintenance. From the beginning of the concept formation until 2012, when at the United Nations Conference on Sustainable Development (Rio+20, 2012) "governments decided to establish an intergovernmental process under the General Assembly to prepare options on a strategy for sustainable development financing" (The future we want, 2012), there was no indication about clear investment sources in SD implementation. Later on, the first report named "Intergovernmental Committee of Experts on Sustainable Development Financing" was formed (ICESDF, 2014), 

sustainable development. a case of Baltic States for the period 2003-2017

defining general options about Domestic and International public and private financing opportunities. Despite the Addis Ababa Action Agenda (AAAA, 2015) which aim was to provide the framework to finance defined global ambitions presented as 17 Sustainable Development Goals (SDGs) (Transforming our world: the 2030 Agenda for Sustainable Development, 2015), there is an official opinion that the situation for SD financing should be examined through a broader lens and urgently needs to be re-focused, stating clear opinion that "Financing for sustainable development is not a cost; it is an investment" (OECD, 2018).

Another issue is the measurement and evaluation of SD results. As country's SD has lots of different indicators in every main area (Social, Economic, and Environmental), on the global scale there are more than 500 indicators (Parris \& Kates, 2003) on the local (Lithuania) scale there were 77 indicators but later according to EU recommendation list there were added more indicators and now there are about 100 indicators in total (Čiegis \& Ramanauskienè, 2011). There are many invented different ways to measure SD in a country, but one of the most popular used is an index.

The General Sustainable Development Goals Index for the first time were mentioned in the report 2016 SDG Index and Dashboard (SDGI, 2016a) and present the report until the year 2018. In this case, as it has to be calculated for the necessary period 2003-2017, the timeline is not enough and the methodology is not described for public use. In this paper, the results of SD of a country are calculated by Integrated Sustainable Development Index (ISDI) by adding the most suitable and with a full-time series SD goal indicators.

To sum up all the information, any country faces two issues while running the process of sustainable development, the investment sources for sustainability and the way to measure the results. So the object of the research is - the investments sources for SD in Lithuania, Latvia, and Estonia. The purpose of the paper is to investigate the different investment sources for sustainable development of a country and reveal the interaction between investment sources for sustainability and a country's sustainable development. The research period is 2003-2017.

\section{Sustainable development index as one of the sustainability measurement option}

Sustainable development is a popular and important concept, but one that is open to a variety of interpretations. Since the 1987 Brundtland report (World Commission on Environment and Development, 1987), many researchers in universities, environmental organizations, think-tanks, national governments, and international agencies have offered proposals for measuring sustainable development (UNECE, 2009). It can be measured in various ways, types, analyses, and methodologies based on different authors.

Measuring by process models, which intention is to find synergies in applying a process view on different systems for SD measurements (Isaksson \& Garvare, 2003). Measuring by Ecological Footprint, which highlights the reality of the limited biological carrying capacity of the planet (Moran, Wackernagel, Kitzes, Goldfinger, \& Boutaud, 2008). Measuring the values that underlie SD by evaluating: survey, Confirmatory factor analyses (CFA), convergent and discriminant validity, performing using Lisrel 8.80, testing with marker variable strategy. And this study develops a reliable and valid measure of values underlying sustainable development which will hopefully stimulate further research on regional, cultural, and demographic differences in sustainable development (Shepherd, Kuskova, \& Patzelt, 2009). It can be measured even by combining and evaluating different results from a time-series analysis: green national net product, Genuine Savings, ecological footprint, Indicator of Sustainable Economic Welfare, Genuine Progress Indicator, Pollution-sensitive Human Development Indicator, Sustainable Human Development Indicator (Nourry, 2008)

The key role of evaluating the countries' progress towards sustainability plays sustainability indicators. The system of indicators is required for the estimation and later provision of policy recommendations (Grybaite, 2011).

Indexes measuring starting in the eighties of the twentieth century and continues until these days. Based on different scientific sources there are many and different sustainable development indicators measuring indexes (Table 1). Therefore, it is necessary to select the most appropriate index according to the criteria which are needed. It consists of three umbrellas or general categorization areas. These areas are 1) indicators and indices, which are further broken down into non-integrated and integrated, 2) product-related assessment tools with the focus on the material and/or energy flows of a product or service from a life cycle perspective, and 3) integrated assessment, which is a collection of tools usually focused on policy change or project implementation (Ness, Urbel-Piirsalu, Anderberg, \& Olsson, 2007). According to the scientists for the local scale index calculations is the third group needed. Main of the indexes are shown and explained in Table 1.

Many economists have spoken out against the narrowly understood development goal of maximizing revenue growth. It was clear that real GDP per capita was not enough. Therefore, the emphasis was placed on "qualitative growth" encompassing broader development criteria such as poverty reduction, access to health care, education, urbanization, environmental protection (Čiegis, 2008). The main advantage of the (ISDI) calculation methodology is that this methodology is flexible enough to accommodate any sustainable development assessment period and crosscutting, choosing the sustainability aspects that best reflect the state's development and the desired level of sustainability. For example, if a certain aspect of sustainability becomes obsolete, it can be removed or replaced, if other aspects relevant to sustainable development appear, they can be included instead of the former or simply supplementing the entire computing system with a larger number of indicators (Čiegis \& Ramanauskienè, 2011). 
Lapinskaite, I.; Janulevičius, P. 2019. The investigation of the impact of investment sources for sustainability on country's sustainable development. a case of Baltic States for the period 2003-2017

Table 1. Sustainable development indexes (compiled by authors)

\begin{tabular}{|c|c|c|}
\hline Index & Author(s) & Main idea / Goal \\
\hline $\begin{array}{l}\text { The measure of } \\
\text { Economic Welfare } \\
(\mathrm{MEW})\end{array}$ & $\begin{array}{l}\text { Nordhaus and } \\
\text { Tobin (1972) }\end{array}$ & $\begin{array}{l}\text { The MEW includes corrections of conventional Net National Product (NNP) in the } \\
\text { areas of Non-market activities and leisure time, Consumer durables, Instrumental or } \\
\text { defensive expenditures, Disamenities of urbanization, Government expenditures. }\end{array}$ \\
\hline $\begin{array}{l}\text { Genuine Progress } \\
\text { Index (GPI) }\end{array}$ & $\begin{array}{l}\text { Daly and Cobb } \\
\text { (1989) }\end{array}$ & $\begin{array}{l}\text { One of the most ubiquitously applied alternatives to Gross Domestic Product (GDP) } \\
\text { in sustainable development research and policy settings. Unlike GDP and related } \\
\text { measures that have a dubious connection to economic welfare, the GPI attempts to } \\
\text { measure it directly by accounting for the benefits of both market and nonmarket } \\
\text { goods and services as well as the economic, social, and environmental costs of } \\
\text { economic activity. }\end{array}$ \\
\hline $\begin{array}{l}\text { Human } \\
\text { Development Index } \\
\text { (HDI) }\end{array}$ & $\begin{array}{l}\text { Human } \\
\text { Development } \\
\text { Reports Office } \\
\text { (UNDP, 1990) }\end{array}$ & $\begin{array}{l}\text { The HDI was created to emphasize that people and their capabilities should be the } \\
\text { ultimate criteria for assessing the development of a country, not economic growth } \\
\text { alone. The HDI can also be used to question national policy choices, asking how two } \\
\text { countries with the same level of GNI per capita can end up with different human } \\
\text { development outcomes. }\end{array}$ \\
\hline $\begin{array}{l}\text { Sustainable Net } \\
\text { Benefit Index } \\
\text { (SNBI) }\end{array}$ & $\begin{array}{l}\text { Lawn and } \\
\text { Sanders (1999) }\end{array}$ & $\begin{array}{l}\text { The sustainable economic welfare of a nation depends largely on the sustainable net } \\
\text { benefits the macroeconomy confers to its citizens. Main indicators: Private } \\
\text { consumption expenditure, An index of distributional inequality, Distributional } \\
\text { weighting of private consumption expenditure, Annual services yielded by stock of } \\
\text { consumer durables, Annual services yielded by stock of public dwellings, roads and } \\
\text { highways, Non-paid household labour, Volunteer labour, Public expenditure on } \\
\text { health and education counted as consumption, Net capital growth, Change in net } \\
\text { international position, Imputed value of leisure time. }\end{array}$ \\
\hline $\begin{array}{l}\text { Environmental } \\
\text { Sustainability Index } \\
\text { (ESI) }\end{array}$ & ESI (2001) & $\begin{array}{l}\text { Benchmarks the ability of nations to protect the environment over the next several } \\
\text { decades. It does so by integrating } 76 \text { data sets - tracking natural resource } \\
\text { endowments, past and present pollution levels, environmental management efforts, } \\
\text { and the capacity of a society to improve its environmental performance - into } 21 \\
\text { indicators of environmental sustainability. These indicators permit comparison } \\
\text { across a range of issues that fall into the following five broad categories: } \\
\text { Environmental Systems; Reducing Environmental Stresses; Reducing Human } \\
\text { Vulnerability to Environmental Stresses; Societal and Institutional Capacity to } \\
\text { Respond to Environmental Challenges; Global Stewardship. }\end{array}$ \\
\hline $\begin{array}{l}\text { Integrated of } \\
\text { Sustainable } \\
\text { Development Index } \\
\text { (ISDI) }\end{array}$ & Čiegis (2008) & $\begin{array}{l}\text { Indicators are simple, usually quantitative measures, reflecting the economic, social } \\
\text { and/or environmental development status of a given region, most often at a country } \\
\text { level. Most useful because indicators can be chosen freely. }\end{array}$ \\
\hline $\begin{array}{l}\text { Sustainable } \\
\text { Development Goals } \\
\text { (SDG) Index and } \\
\text { Dashboards Report }\end{array}$ & $\begin{array}{l}\text { Sachs, Kroll, } \\
\text { Schmidt-Traub, } \\
\text { Lafortune, } \\
\text { Fuller, (SDGI, } \\
\text { 2016b) }\end{array}$ & $\begin{array}{l}\text { The SDG Index creates for the first time a measure of the SDG starting point for } 2015 \\
\text { at the country level. It will help every country identify priorities for early action, } \\
\text { understand the key implementation challenges and identify the gaps that must be } \\
\text { closed in order to achieve the SDGs by } 2030 \text {. The SDG Index also allows each } \\
\text { country to compare itself with the region, with other counterparts at similar levels of } \\
\text { overall economic development, and with the entire world, including the best and } \\
\text { worst performers. }\end{array}$ \\
\hline
\end{tabular}

Based on the authors, the ISDI, will be analysed because of three main facts: it can be calculated with the selected (needed) indicators, secondly, it is suitable for local area (in this case - Baltic States), and the third - it has no established indicators and in that case it is possible to choose them according to the author or for the other reasons, for example, according to the main countries sustainable development goals by the newest strategies or choose any other SD goal set by United Nations.

\section{The overview of different investments sources for sustainable development in the Baltic States}

State economic and social development is closely related to the financial system and its sustainable activities. The financial system has an impact on economic, social and other needs, as it helps to build the state's financial resources. The development of the economy, the satisfaction of public needs, the maintenance of government and management bodies, etc. depend on the quantity, formation, and use of financial resources. Formation of financial resources depends on how fiscal policy is implemented and on the volume of public assets. The country's financial system consists of three strands: business finance, public finance, and personal finance (Rutkauskas, 2014). These (or at least some) of these strands can be found in all Baltic States strategies as relevant investment source in sustainable development. In the case of Latvia, it is possible to point out: state and local government budget, the private sector, non-governmental 

sustainable development. a case of Baltic States for the period 2003-2017

organizations and other sources (Saeima of the Republic of Latvia, 2010). In the case of Estonia, it is possible to distinguish: state and local government budget, The Estonian Environmental Investment Centre and cooperation with several NGOs and companies (Government of Estonia, 2016). In the case of Lithuania: state and local government budget, EU structural funds, companies investments, Foreign direct investment, Risk Sharing Fund (In cooperation with the European Investment Bank), private investors (Lietuvos Respublikos Vyriausybè, 2018).

Lithuania, Latvia, and Estonia are classified as Developed countries (United Nations, 2018). Developed countries require foreign capital inflows for sustainable development. FDI may bring significant benefits by creating high-quality jobs, introducing modern production and management practices (Saini \& Singhania, 2018). EU Structural Funds is a good tool as an investment source in member states. For example, which can be used to attract investments for the financing of new technologies, including the use of renewable energy sources and energy efficiency improvements (renewable energy projects) which are doubly underpowered by energy markets and needs state support (Dapkus \& Streimikiene, 2016).

In general, because of any suggestions on how countries have to manage their investments in development, every country was forming their own investing options. Various scientists and researchers evaluated, wrote articles, studies on different investment sources interactions with SD. It could be seen that all investments are based on areas of the country's financial system. In addition, for all Baltic States, it is possible to distinguish three main investments sources: Assignation of the budget, European Union structural funds, Direct investments.

From all these findings, not all the funds are used in sustainability. For this research will be analysed the following data:

- Assignation of budget which will be represented as general government expenditures in functions: Economic affairs (General economic, commercial and labour affairs; Agriculture, forestry, fishing and hunting; Fuel and energy; Mining, manufacturing and construction; Transport; Communication; Other industries; R\&D Economic affairs), Environmental protection (Waste management; Wastewater management; Pollution abatement; Protection of biodiversity and landscape; R\&D Environmental protection), Housing and community amenities (Housing development; Community development; Watersupply; Street lighting; R\&D Housing and community amenities), Health (Medical products, appliances and equipment; Outpatient services; Hospital services; Public health services; R\&D Health), Education (Pre-primary and primary education; Secondary education; Post-secondary non-tertiary education; Tertiary education; Education not definable by level; Subsidiary services to education; R\&D Education), Social protection (Sickness and disability; Old age; Survivors; Family and children; Unemployment; Housing; Social exclusion; R\&D Social protection) (EC. Europa, 2018a).

-EU structural funds will be represented as the sum of all programming periods with their main funds: Cohesion Fund (CF); European Regional Development Fund (ERDF); European Social Fund (ESF); European Agricultural Fund for Rural Development (EAFRD); European Maritime and Fisheries Fund (EMFF). By periods it will be: 2000-2006 period (CF, EAFRD, ESF, ERDF); 2007-2013 period (CF, EAFRD, ESF, ERDF); 2014-2020 period (CF, EAFRD, ESF, ERDF and EMFF). Because the purpose of all these funds is to invest in job creation and a sustainable and healthy European economy and environment (EC. Europa, 2018b).

-Direct investments by field of activity: Water supply, sewerage, waste management and remediation activities (E); Transportation and storage (H); Information and communication (J); Professional, scientific and technical activities (M); Education (P); Human health and social work activities (Q) (Statistika.eestipank, 2018; Statdb.bank, 2018; Osp.stat.gov, 2018).

To sum up, three main investment sources can be distinguished: Assignation of the budget, European Union structural funds and Foreign direct investments with priority branches most concerned with sustainable development.

\section{Methodology for Integrated Sustainable Development Index and correlation regression analysis}

The analysis consists of two main calculations: Integrated Sustainable Development Index (ISDI) and Correlation regression analysis. ISDI is calculated and interpreted as an expression of SD results for Lithuania, Latvia, and Estonia. Correlation regression analysis is used in order to evaluate the relationship between the investment sources for sustainability and SD for analysed countries, which is expressed as ISDI.

ISDI can be calculated according to Čiegis and Ramanauskienè (2011) formulas: 1-3. The basic ISDI formula is:

$$
I_{S D I}=\sum_{i} a_{i} I_{i}
$$

where: $I_{i}$ - indices of individual aspects of sustainable development; $a_{i}$ - weights for indices of individual aspects of sustainable development (with the condition: $\sum_{i} a_{i}=1$ ). 

sustainable development. a case of Baltic States for the period 2003-2017

The standardized sustainable development index includes three aspects of sustainable development - economic, social and ecological, summing up the economic development $\left(I_{E V}\right)$, the social development $\left(I_{S V}\right)$ and the state of the environment-development $\left(I_{E B}\right)$ indices:

$$
I_{S D}=a_{1} I_{E V}+a_{2} I_{S V}+a_{3} I_{A V}
$$

Each one of these three indices $\left(I_{E V}, I_{S V}, I_{A B}\right)$ consist of indicators (the indicators used in this article are presented in chapter 4) in general it can be expressed in the form:

$$
I_{m}=\sum_{i} a_{i} R_{i}
$$

where: $R_{i}$-indicator for the index; $a_{i}$ - the weight of indicator for the index (with the condition: $\sum_{i} a_{i}=1$ ). $I_{m}-$ index.

If the formation of an integrated index increases the values of certain indicators that make up it, it is considered to be a positive and desirable process, the index variation from 0 to any higher values should mark a favourable process and the indices that decrease as a desirable process are re-indexed.

The calculation is based on the principle of chain indicators, i.e. compared to last year. All areas of sustainable development are equivalent, so the most optimal result would be when all areas grow equally - both in size and pace.

Correlation analysis allows us to estimate the relationship between independent variables (in the article: $\mathrm{X}_{1}-$ assignation of the budget, $\mathrm{X}_{2}-$ EU structural funds, $\mathrm{X}_{3}-$ Direct investments) with the dependent variable (Y Integrated of sustainable development index). Using this analysis it is possible to determine which independent variables are essentials and whether they correlate with the dependent variable. If this relationship is strong, there is also a functional relationship that is determined during the regression analysis with each independent variable (paired analysis is estimated) or with all the variables together (multiple regression analysis). Correlation regression analysis can be calculated according to Valavičius (2006) formulas: 4-7.

Correlation coefficient - is a correlation strength measure that determines the relationship between variables. Calculated according to the formula:

$$
r=\frac{n \sum x_{i} y_{i}-\sum x_{i} \sum y_{i}}{\sqrt{n \sum x_{i}^{2}-\left(\sum x_{i}\right)^{2}} \sqrt{n \sum y_{i}^{2}-\left(\sum y_{i}\right)^{2}}},
$$

where: $r$-correlation coefficient; $x_{i}, y_{i}$-values of variables; $n$ - the size of the sample.

If two or more variables have a relationship, it is said that they correlate. Variables can be related in two ways: correlation direction and strength. Correlation direction: Positive (direct correlation); Negative (reverse correlation); Zero relationship (no correlation).

Correlation strength, which indicates the degree to which the variables correlate positively or negatively. The higher the degree, the stronger the relationship. The correlation strength is measured between $-1<r<1$.

To verify that $X$ 's are suitable for regression analysis, it is necessary to find if the correlation coefficient is statistically significant. For that $t$ criteria is calculated using the following formula:

$$
t=\left|r \cdot \sqrt{\frac{n-2}{1-r^{2}}}\right| .
$$

The correlation coefficient is significant, i.e. significantly differs from zero, if:

$$
t>t_{\infty,(n-2)}^{c r}
$$

where: $t_{\infty,(n-2)}^{k r}$ - Student's distribution with degrees of freedom $(n-2)$ and with significance level $\alpha=0,05$.

If $t$ value is greater than $t_{c r}$, the correlation coefficient is statistically significant (the stochastic relationship between variables exists).

If a stochastic relationship exists between variables, a multiple correlation regression analysis can be performed.

This analysis determines the existence of a general relationship between $Y$ and all selected factors $X$ and its analytical expression (equation). Model of linear regression equation (based on the general relationship between $Y$ and $X)$ :

$$
\hat{y}=a_{0}+a_{1} x_{1}+a_{2} x_{2}+\cdots+a_{i} x_{i}
$$

Multiple correlation analysis can be performed using Excel's functions: LINEST (evaluates linear factor coefficients) and LOGEST (evaluates exponential factor coefficients). The most important data in the table made by these functions: the upper line which sets out the equation (helps to predict the expected result when changing the $\mathrm{X}$ values): $a_{0}, a_{i}$. The second important value is in $3^{\text {rd }}$ line $1^{\text {st }}$ column - the determination coefficient $\left(\mathrm{D}=\mathrm{R}^{2}\right)$, which 

sustainable development. a case of Baltic States for the period 2003-2017

potentially explains the scattering of statistical points (shows the reliability of the equation), reliable results are considered when the coefficient is more than 0.6 . And the third important value is in $4^{\text {th }}$ line $1^{\text {st }}$ column - the $\mathrm{F}$ Experimental $(\mathrm{F})$ which helps to find out if the means between two populations are significantly different. If the $\mathrm{F}$ Experimental is greater than the $\mathrm{F}$ Critical $\left(\mathrm{F}_{\mathrm{cr}}\right)$ value, the null hypothesis fails and the linear model is significant. $\mathrm{F}$ Critical value can be performed using Excel's function: FINV specifying the values: $\alpha=0,05 ; \mathrm{v}_{1}=\mathrm{m} ; \mathrm{v}_{2}=\mathrm{n}-\mathrm{m}-1$. Where: $\alpha$ - significance level; $\mathrm{m}$ - the number of variables; $\mathrm{n}$ - number of data points (Pabedinskaite \& Činčikaite, 2016).

Summarized, first of all, it is necessary to make a pair correlative analysis and if the results show the correlation between the dependent and independent variables it is possible to make multiple correlation regression analysis.

\section{The analysis of the impact of investment for sustainability on Baltic countries' sustainable development for the period 2003-2017}

As scientific practice witness, any task-oriented analysis requires a short-list of indicators otherwise comparisons of the countries and sustainable development management process are hardly feasible (Grybaite, 2011). For measuring sustainable development, it is common to select and match a certain number of indicators for each of the three (or more) dimensions - economic, ecological, social, etc. (Čiegis \& Ramanauskienė, 2011). The following indicators were evaluated for ISDI calculations according to Eurostat Sustainable Development Goals data with a full-time series and a link to important indicators. Economic: GDP (current prices, euro per capita); Purchasing power adjusted GDP per capita (Real expenditures per capita, in PPS); Employment rate (as percentage of population aged 20 to 64); Gross domestic expenditures on R\&D (as percentage of GDP); Energy productivity (in euro per kg oil equivalent). Social: People at risk of poverty or social exclusion (Percentages); Early leavers from education and training (as the percentage of the population aged 18 to 24); Expenditure on social protection (percentage of GDP); Live births (total); Fatal road accidents (per 100000 persons). Environmental: Greenhouse gas emissions (thousand tonnes); Energy productivity (in euro per kg oil equivalent); Gross nitrogen balance on agricultural land (kg per hectare); Share of renewable energy (as percentage gross final energy consumption); Phosphates in rivers (mg PO4 per litre) (EC. Europa, 2018c). ISDI represented in Figure 1 from statistical data in Appendixes 1-3.

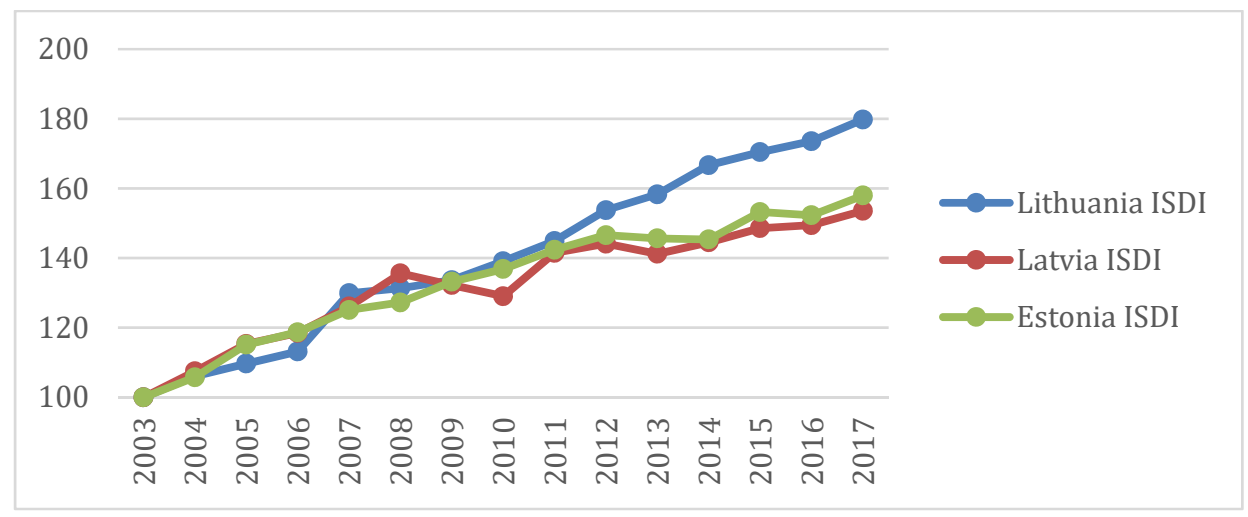

Figure 1. The dynamic of ISDI of Baltic countries for the period 2003-2017 (compiled by authors)

From the ISDI results, it is clear that all countries are growing gradually: Lithuania grew by 79.80 points, growing gradually every year and is in the first place by index. Latvia grew by 53.56 points with small downturns in 2009 by 3.36 points, in 2010 by 3.2 points and in 2013 by 2.89 points and is in the third place. Estonia grew by 57.99 points with small downturns in 2013 by 0.94 points, in 2014 by 0.31 points and in 2016 by 0.93 points, and is in the second place of Baltic States. In general, it is possible to point out, that all countries were growing in SD from 2003 as a basic year but Lithuania has the biggest growth rate.

In the second part of the analysis (Tables 2, 3 and 4), ISDI set as the dependent variable (Y), according to formulas: 1-3. The following independent variables were chosen for the research: $\mathrm{X}_{1}-$ Assignation of Budget (MEUR); $\mathrm{X}_{2}$ - European Union Structural Funds (MEUR); $\mathrm{X}_{3}$ - Foreign direct investment (MEUR).

From the results, it is necessary to point out that ISDI is increasing gradually every year with all the investments as well except some of them have small fluctuations for all Baltic States. Secondly, all three investment sources have a positive very strong relationship, except EU structural funds for Latvia have a strong positive relationship, in any case, that means that all sources are strongly affecting sustainable development. $t>t_{c s}$, for each source, that means that stochastic relationship exists between variables and it is possible to evaluate the multiple correlation analysis. 
Lapinskaite, I.; Janulevičius, P. 2019. The investigation of the impact of investment sources for sustainability on country's sustainable development. a case of Baltic States for the period 2003-2017

Table 2. Data for correlation analysis of ISDI and investment for a country's sustainability.

The case of Lithuania results (compiled by authors).

\begin{tabular}{|c|c|c|c|c|}
\hline \multicolumn{5}{|c|}{ Lithuania } \\
\hline & ISD & $\begin{array}{c}\text { Assignation of Budget } \\
\text { (MEUR) }\end{array}$ & $\begin{array}{l}\text { EU Structural Funds } \\
\text { (MEUR) }\end{array}$ & $\begin{array}{l}\text { Direct investments } \\
\text { (MEUR) }\end{array}$ \\
\hline 2003 & 100.00 & 4193.4 & 32.9 & 793.5 \\
\hline 2004 & 106.09 & 4559.2 & 107.4 & 939.2 \\
\hline 2005 & 109.68 & 5230.0 & 181.3 & 1329.7 \\
\hline 2006 & 113.17 & 6175.6 & 224.9 & 1621.8 \\
\hline 2007 & 129.90 & 7736.0 & 555.9 & 2001.2 \\
\hline 2008 & 131.34 & 9720.3 & 737.6 & 1838.1 \\
\hline 2009 & 133.67 & 9682.4 & 1443.4 & 1841.2 \\
\hline 2010 & 139.09 & 9435.3 & 1176.4 & 2006.2 \\
\hline 2011 & 144.92 & 10582.4 & 1214.8 & 2205.8 \\
\hline 2012 & 153.76 & 9334.8 & 1260.8 & 2420.1 \\
\hline 2013 & 158.31 & 9355.3 & 1305.4 & 2544.0 \\
\hline 2014 & 166.68 & 9650.6 & 1286.4 & 2549.3 \\
\hline 2015 & 170.44 & 9983.7 & 938.8 & 2699.4 \\
\hline 2016 & 173.56 & 10092.9 & 1238.1 & 2785.1 \\
\hline 2017 & 179.80 & 10551.7 & 1645.3 & 2963.3 \\
\hline \multicolumn{2}{|c|}{$\mathrm{r}$} & 0.9 & 0.9 & 1.0 \\
\hline \multicolumn{2}{|c|}{ Variable relationship } & Positive very strong & Positive very strong & Positive very strong \\
\hline \multicolumn{2}{|c|}{$\mathrm{t}$} & 4.8 & 4.8 & 12.7 \\
\hline \multicolumn{2}{|c|}{$t_{c r}$} & \multicolumn{3}{|c|}{2.2} \\
\hline
\end{tabular}

Table 3. Data for correlation analysis of ISDI and investment for a country's sustainability.

The case of Latvia results (compiled by authors).

\begin{tabular}{|c|c|c|c|c|}
\hline \multicolumn{5}{|c|}{ Latvia } \\
\hline & ISD & $\begin{array}{c}\text { Assignation of Budget } \\
\text { (MEUR) }\end{array}$ & $\begin{array}{l}\text { EU Structural Funds } \\
\text { (MEUR) }\end{array}$ & $\begin{array}{l}\text { Direct investments } \\
\text { (MEUR) }\end{array}$ \\
\hline 2003 & 100.00 & 2628.1 & 22.7 & 407.0 \\
\hline 2004 & 107.47 & 2995.2 & 85.6 & 594.0 \\
\hline 2005 & 115.35 & 3527.6 & 159.2 & 688.0 \\
\hline 2006 & 118.48 & 4540.2 & 171.3 & 817.0 \\
\hline 2007 & 126.08 & 5568.2 & 476.1 & 912.0 \\
\hline 2008 & 135.61 & 6916.8 & 456.2 & 927.0 \\
\hline 2009 & 132.25 & 6464.4 & 584.7 & 874.0 \\
\hline 2010 & 129.05 & 6415.6 & 674.6 & 903.0 \\
\hline 2011 & 141.48 & 6297.9 & 732.9 & 943.0 \\
\hline 2012 & 144.11 & 6384.6 & 974.1 & 933.0 \\
\hline 2013 & 141.22 & 6508.5 & 810.2 & 908.0 \\
\hline 2014 & 144.52 & 6792.9 & 818.2 & 1122.0 \\
\hline 2015 & 148.59 & 6972.0 & 663.9 & 1443.0 \\
\hline 2016 & 149.45 & 6889.9 & 837.8 & 1536.0 \\
\hline 2017 & 153.56 & 7023.0 & 949.6 & 1917.0 \\
\hline \multicolumn{2}{|c|}{$\mathrm{r}$} & 1.0 & 0.7 & 0.9 \\
\hline \multicolumn{2}{|c|}{ Variable relationship } & Positive very strong & Positive strong & Positive very strong \\
\hline \multicolumn{2}{|c|}{$\mathrm{t}$} & 11.3 & 2.7 & 7.2 \\
\hline \multicolumn{2}{|c|}{$t_{c r}$} & \multicolumn{3}{|c|}{2.2} \\
\hline
\end{tabular}


Lapinskaite, I.; Janulevičius, P. 2019. The investigation of the impact of investment sources for sustainability on country's sustainable development. a case of Baltic States for the period 2003-2017

Table 4. Data for correlation analysis of ISDI and investment for a country's sustainability. The case of Estonia results (compiled by authors).

\begin{tabular}{|c|c|c|c|c|}
\hline \multicolumn{5}{|c|}{ Estonia } \\
\hline & ISD & $\begin{array}{c}\text { Assignation of Budget } \\
\text { (MEUR) }\end{array}$ & $\begin{array}{l}\text { EU Structural Funds } \\
\text { (MEUR) }\end{array}$ & $\begin{array}{l}\text { Direct investments } \\
\text { (MEUR) }\end{array}$ \\
\hline 2003 & 100.00 & 2233.7 & 15.6 & 1046.2 \\
\hline 2004 & 105.78 & 2473.2 & 60.2 & 508.0 \\
\hline 2005 & 115.12 & 2820.3 & 98.3 & 536.8 \\
\hline 2006 & 118.69 & 3335.3 & 154.5 & 920.8 \\
\hline 2007 & 125.11 & 4111.7 & 234.1 & 789.1 \\
\hline 2008 & 127.24 & 4932.8 & 288.8 & 1736.5 \\
\hline 2009 & 133.21 & 5008.1 & 598.3 & 2355.8 \\
\hline 2010 & 136.84 & 4579.6 & 662.3 & 2378.5 \\
\hline 2011 & 142.40 & 4753.6 & 383.3 & 2400.2 \\
\hline 2012 & 146.59 & 5321.8 & 802.7 & 2643.5 \\
\hline 2013 & 145.65 & 5434.7 & 805.2 & 2781.2 \\
\hline 2014 & 145.34 & 5657.9 & 479.3 & 2942.5 \\
\hline 2015 & 153.22 & 6171.4 & 191.3 & 2994.2 \\
\hline 2016 & 152.29 & 6324.1 & 274.3 & 3245.5 \\
\hline 2017 & 157.99 & 6643.5 & 857.4 & 3301.5 \\
\hline \multicolumn{2}{|l|}{$\mathrm{r}$} & 0.9 & 0.9 & 0.8 \\
\hline \multicolumn{2}{|c|}{ Variable relationship } & Positive very strong & Positive very strong & Positive very strong \\
\hline \multicolumn{2}{|l|}{$\mathrm{t}$} & 7.6 & 7.6 & 4.4 \\
\hline \multicolumn{2}{|l|}{$t_{c r}$} & \multicolumn{3}{|c|}{2.2} \\
\hline
\end{tabular}

From the multiple regression analysis results (Appendixes 4-6) the following equations could be presented:

$$
\begin{aligned}
& \hat{y}_{E E}=80.38+0.009 x_{1}+0.005 x_{2}+0.003 x_{3} ; \\
& \hat{y}_{L V}=86.33+0.004 x_{1}+0.019 x_{2}+0.012 x_{3} ; \\
& \hat{y}_{L T}=71.05+0.002 x_{1}+0.009 x_{2}+0.037 x_{3} .
\end{aligned}
$$

It shows that adding 1 extra million euros to each source $\left(\mathrm{X}_{1}, \mathrm{X}_{2}, \mathrm{X}_{3}\right)$ SDI will increase by $0.009 ; 0.005 ; 0.003$ points for Estonia, by $0.004 ; 0.019 ; 0.012$ points for Latvia and by $0.002 ; 0.009 ; 0.037$ points for Lithuania. In general, all three Baltic States needs a lot of investments to significantly increase the value of SD.

F Experimental and F Critical values are:

$$
\begin{gathered}
F_{E E}=69.525256 ; \\
F_{L V}=98.877177 ; \\
F_{L T}=85.004166 ; \\
F_{c r}=8.702870 .
\end{gathered}
$$

In all cases, If the F Experimental is greater than the F Critical value, the linear model is significant. And 95 percentages sure that data is not a random scatter of points and that the regression is justified.

Following the results, determination coefficients (D) equals to 0.9499 (Estonia), to 0.9642 (Estonia) and to 0.9586 (Estonia), that means that equations explain 94.99 for Estonia, 96.42 for Latvia, 95.86 for Lithuania percentages scattering of statistical points (the equations is very reliable). And these three variables can be as main.

In general, all the calculations results are reliable and can be used to evaluate the impact of different investment sources to sustainable development in Baltic states. Practically applicable for modelling the SD index changes if any of the investment circumstances change due to various reasons. 

sustainable development. a case of Baltic States for the period 2003-2017

\section{Conclusions}

In order to achieve the United Nations Sustainable Development Goals, any country faces many issues, but there are several most important ones. The first is the possibility to see the finance for SD as an investment and not a cost and identify clear investment sources for SD, and the second is a measurement of the results of SD in a country. There are many invented ways to measure SD activities at a country level, but still, due to different reasons, there is no one common measurement tool suitable and convenient to use globally. That is why ISDI was applied for this research. The main advantage of this index calculation methodology is that this methodology is flexible enough to accommodate any sustainable development assessment period and cross-cutting, choosing the sustainability aspects that best reflect the state's development and the desired level of sustainability. But there is an answered question, how the results will change if another index would be used as a representation of a country's SD results.

For all the analysed Baltic states the three main investment sources: assignations of the state budget, EU structural funds, and direct investments, were evaluated and analysed. This could be seen as a limitation of the research because the AAAA (2015) suggest to diversify the sources of financing into all levels, starting household businesses and finally state.

The findings of the research show that ISDI is increasing gradually every year for all analysed countries: Lithuania, Latvia, and Estonia. All three investment sources have a positive very strong (or at least positive strong) relationship, that means that sources are strongly affecting countries sustainable development, and stochastic relationship exists between variables. Adding 1 extra million euros to each source (X1, X2, X3) can increase SDI by $0.009 ; 0.005 ; 0.003$ points for Estonia, by $0.004 ; 0.019 ; 0.012$ points for Latvia and by $0.002 ; 0.009 ; 0.037$ points for Lithuania. Following the results, determination coefficients (D) equals to 0.9499 (Estonia), to 0.9642 (Estonia) and to 0.9586 (Estonia), that means that equations explain 94.99 for Estonia, 96.42 for Latvia, 95.86 for Lithuania percentages scattering of statistical points (the equations is very reliable).

For the further research deeper analysis of the investment sources for SD of a country should be carried out and other investment sources for SD have to be distinguished. In order to ascertain the cause of the obtained results, it would be appropriate to carry out the research including more investment sources for other developed EU countries.

\section{References}

AAAA. (2015). The Addis Ababa Action Agenda. Retrieved from https://www.un.org/esa/ffd/wpcontent/uploads/2015/08/AAAA_Outcome.pdf

Čiegis, R. (2008). Darnus ekonomikos vystymasis: Mokomoji kmyga. Šiauliai: VšĮ Šiaulių universiteto leidykla. 204 p.

Čiegis, R., \& Ramanauskienè, J. (2011). Integruotas darnaus vystymosi vertinimas: Lietuvos atvejis. Management Theory and Studies for Rural Business and Infrastructure Development, 2(26), 12.

Daly, H. E., \& Cobb, J. B. (1989). For the common good: Redirecting the economy toward community, the environment, and a sustainable future. Beacon Press. 482 p.

Dapkus, R., \& Streimikiene, D. (2016). Impact of use of European Union Structural funds for sustainable development in the member states. International Journal of Trade, Economics and Finance, 7(2), 25.

EC. Europa. (2018a). General government expenditure by function. Retrieved from https://ec.europa.eu/eurostat/tgm/table.do?tab=table\&init=1\&plugin=1\&pcode=tepsr_sp110\&language=en

EC. Europa. (2018b). European structural and investment funds. Retrieved from https://ec.europa.eu/info/fundingtenders/funding-opportunities/funding-programmes/overview-funding-programmes/european-structural-and-investmentfunds en

EC. Europa. (2018c). SDG indicators: goal by goal. Retrieved from https://ec.europa.eu/eurostat/web/sdi/indicators

Grybaite, V. (2011). Towards measurement of sustainable development: Systems of indicators. Journal of Security and Sustainability Issues, 1(1). 19-26. https://doi.org/10.9770/jssi.2011.1.1(2)

ICESDF. (2014). Report of the intergovernmental committee of experts on sustainable development financing. Retrieved from https://sustainabledevelopment.un.org/content/documents/4588FINAL\%20REPORT\%20ICESDF.pdf

Isaksson, R., \& Garvare, R. (2003). Measuring sustainable development using process models. Managerial Auditing Journal, 18(8), 649-656. https://doi.org/10.1108/02686900310495142

Lawn, P. A., \& Sanders, R. D. (1999). Has Australia surpassed its optimal macroeconomic scale? Finding out with the aid of 'benefit' and 'cost' accounts and a sustainable net benefit index. Ecological Economics, 28(2), 213-229. Retrieved from https://doi.org/10.1016/s0921-8009(98)00049-4

Lietuvos Respublikos Vyriausybè. (2018). Nacionalinès JT Darnaus vystymosi darbotvarkès iki 2030 m. igyvendinimo Lietuvoje ataskaita. Retrieved from http://am.lrv.lt/lt/veiklos-sritys-1/es-ir-tarptautinis-bendradarbiavimas/darnus-vystymasis/darnusvystymasis-ir-lietuva/jt-darbotvarkes-2030-igyvendinimo-lietuvoje-ataskaita

Moran, D., Wackernagel, M., Kitzes, J., Goldfinger, S. H, \& Boutaud, A. (2008). Measuring sustainable development - nation by nation. Ecological Economics, 64, 470-474. https://doi.org/10.1016/j.ecolecon.2007.08.017

Ness, B., Urbel-Piirsalu, E., Anderberg, S., \& Olsson, L. (2007). Categorising tools for sustainable assessment. Ecological Economics, 60(30), 498-508. https://doi.org/10.1016/j.ecolecon.2006.07.023

Nordhaus, W. D., \& Tobin, J. (1972). Is Growth Obsolete?. In Economic Research: Retrospect and Prospect (Vol. 5, Economic Growth, pp. 1-80). New York. Retrieved from https://www.nber.org/chapters/c7620

Nourry, M. (2008). Measuring sustainable development: Some empirical evidence for France from eight alternative indicators. Ecological Economics, 67, 441-456. https://doi.org/10.1016/j.ecolecon.2007.12.019 
Lapinskaite, I.; Janulevičius, P. 2019. The investigation of the impact of investment sources for sustainability on country's sustainable development. a case of Baltic States for the period 2003-2017

OECD. (2018). Global outlook on financing for sustainable development 2019: Time to face the challenge. OECD Publishing, Paris. https://doi.org/10.1787/9789264307995-en

Osp.stat.gov. (2018) Statistiniu rodikliu analize. Retrieved from https://osp.stat.gov.lt/statistiniu-rodikliu-analize\#/

Pabedinskaitè, A., \& Činčikaitè, R. (2016). Kiekybiniai modeliavimo metodai: Mokomoji knyga. Vilnius: Technika. 168 p. https://doi.org/10.20334/1563-S

Parris, T. M., \& Kates, R. W. (2003). Characterizing and measuring sustainable development. Annual Review of Environment and Resources, 28(1), 559-586. https://doi.org/10.1146/annurev.energy.28.050302.105551

Rio+20. (2012). United Nations Conference on Sustainable Development, Retrieved from https://sustainabledevelopment.un.org/rio20

Rutkauskas, A. V. (2014). Ižvalgi investavimo strategija puoselejjant universaluji plètros tvarumą: Mokslo monografija. Vilnius: BMK Leidykla. $362 \mathrm{p}$.

Saeima of the republic of Latvia. (2010). Sustainable development strategy of Latvia until 2030. 107. Retrieved from http://sdgtoolkit.org/tool/sustainable-development-strategy-of-latvia-until-2030/

Saini, N., \& Singhania, M. (2018). Determinants of FDI in developed and developing countries: a quantitative analysis using GMM. Journal of Economic Studies, 45(2), 348-382. https://doi.org/10.1108/JES-07-2016-0138

SDG. (2015). Sustainable development goals. Retrieved from https://sustainabledevelopment.un.org/post2015/transformingourworld/publication

SDGI. (2016a). 2016 SDG Index and dashboards. Retrieved from http://sdgindex.org/reports/2016/

SDGI. (2016b). 2016 SDG Index and dashboards. About us. Retrieved from http://sdgindex.org/about-us/

Shepherd, D. A., Kuskova, V., \& Patzelt, H. (2009). Measuring the values that underlie sustainable development: The development of a valid scale. Journal of Economic Psychology, 30(2), 246-256. https://doi.org/10.1016/j.joep.2008.08.003

Statdb.bank. (2018). 02 DI data by kind of activity tables (closing position). Retrieved from https://statdb.bank.lv/lb/Data.aspx?id=131

Statistika. Eestipank (2018). Direct investment position in Estonia and abroad by field of activity. Retrieved from http://statistika.eestipank.ee/\#/en/p/146/r/2017/1866

ESI. (2001). Environmental Sustainability Index. Palisades, NY: NASA Socioeconomic Data and Applications Center (SEDAC). Retrieved from https://doi.org/10.7927/H4X34VDM

The future we want. (2012). The outcome document of the United Nations Conference on Sustainable Development. Retrieved from https://sustainabledevelopment.un.org/content/documents/733FutureWeWant.pdf

The General Assembly. (2000). United Nations Millennium Declaration. Fifty-fifth session Agenda item 60 (b): 9. Retrieved from https://www.un.org/ruleoflaw/blog/document/united-nations-millennium-declaration/

The General Assembly. (2015). Transforming our world: the 2030 Agenda for sustainable development. Seventieth session Agenda items 15 and 116: 35. Retrieved from https://sustainabledevelopment.un.org/post2015/transformingourworld/publication

The government of Estonia. (2016). Review on the implementation of the 2030 agenda in Estonia. Retrieved from http://sdgtoolkit.org/tool/review-on-the-implementation-of-the-2030-agenda-in-estonia/

Transforming our world: the 2030 Agenda for sustainable development. (2015). Resolution adopted by the General Assembly on 25 September 2015. Retrieved from http://www.un.org/ga/search/view_doc.asp?symbol=A/RES/70/1\&Lang=E

UNDP. (1990). Human development report. UNDP, New York. Retrieved from http://hdr.undp.org/sites/default/files/reports/219/hdr_1990_en_complete_nostats.pdf

UNECE. (2009). Measuring sustainable development. Retrieved from https://sustainabledevelopment.un.org/content/documents/801Measuring_sustainable_development.pdf

United Nations. (2018). World economic situation and prospects. Retrieved from https://www.un.org/development/desa/dpad/publication/world-economic-situation-and-prospects-2018/

Valavičius, V. (2006). Matematinis modeliavimas ir eksperimentu planavimas: Mokomoji kmyga. Vilnius: Technika. 128 p. https://doi.org/10.3846/895-S

World Commission on Environment and Development. (1987). Our Common Future. Oxford University Press. 383 p. 
Lapinskaite, I.; Janulevičius, P. 2019. The investigation of the impact of investment sources for sustainability on country's sustainable development. a case of Baltic States for the period 2003-2017

\section{Appendix 1}

Lithuania ISDI by areas (compiled by authors)

\begin{tabular}{|c|c|c|c|c|}
\hline \multicolumn{5}{|c|}{ Lithuania } \\
\hline Year & Economic Index (IEv) & Social Index (Isv) & Environmental Index (IAv) & ISDI \\
\hline 2003 & $33.33(3)$ & $33.33(3)$ & $33.33(3)$ & 100.00 \\
\hline 2004 & 36.01 & 33.72 & 36.35 & 106.09 \\
\hline 2005 & 39.02 & 35.21 & 35.44 & 109.68 \\
\hline 2006 & 42.63 & 35.88 & 34.65 & 113.17 \\
\hline 2007 & 46.68 & 39.73 & 43.49 & 129.90 \\
\hline 2008 & 48.87 & 44.25 & 38.22 & 131.34 \\
\hline 2009 & 44.25 & 48.02 & 41.40 & 133.67 \\
\hline 2010 & 47.34 & 48.62 & 43.14 & 139.09 \\
\hline 2011 & 52.01 & 48.24 & 44.67 & 144.92 \\
\hline 2012 & 54.47 & 49.08 & 50.21 & 153.76 \\
\hline 2013 & 58.02 & 51.52 & 48.77 & 158.31 \\
\hline 2014 & 61.01 & 52.95 & 52.71 & 166.68 \\
\hline 2015 & 62.39 & 55.03 & 53.02 & 170.44 \\
\hline 2016 & 61.57 & 60.48 & 51.51 & 173.56 \\
\hline 2017 & 65.20 & 60.28 & 54.32 & 179.80 \\
\hline
\end{tabular}

\section{Appendix 2}

Latvia ISDI by areas (compiled by authors)

\begin{tabular}{|c|c|c|c|c|}
\hline \multicolumn{5}{|c|}{ Latvia } \\
\hline Year & Economic Index (IEv) & Social Index (Isv) & Environmental Index (I $\left.\mathrm{I}_{\mathrm{Av}}\right)$ & ISDI \\
\hline 2003 & $33.33(3)$ & $33.33(3)$ & $33.33(3)$ & 100.00 \\
\hline 2004 & 35.97 & 34.51 & 36.99 & 107.47 \\
\hline 2005 & 41.43 & 36.28 & 37.64 & 115.35 \\
\hline 2006 & 47.94 & 37.73 & 32.81 & 118.48 \\
\hline 2007 & 51.83 & 38.67 & 35.58 & 126.08 \\
\hline 2008 & 54.07 & 42.49 & 39.05 & 135.61 \\
\hline 2009 & 44.52 & 46.30 & 41.43 & 132.25 \\
\hline 2010 & 46.67 & 49.10 & 33.28 & 129.05 \\
\hline 2011 & 52.44 & 50.86 & 38.19 & 141.48 \\
\hline 2012 & 54.08 & 52.58 & 37.46 & 144.11 \\
\hline 2013 & 54.94 & 53.81 & 32.48 & 141.22 \\
\hline 2014 & 58.00 & 53.97 & 32.55 & 144.52 \\
\hline 2015 & 58.95 & 54.46 & 35.18 & 148.59 \\
\hline 2016 & 56.56 & 58.21 & 34.68 & 149.45 \\
\hline 2017 & 60.65 & 59.28 & 33.64 & 153.56 \\
\hline
\end{tabular}


Lapinskaite, I.; Janulevičius, P. 2019. The investigation of the impact of investment sources for sustainability on country's sustainable development. a case of Baltic States for the period 2003-2017

\section{Appendix 3}

Estonia ISDI by areas (compiled by authors)

\begin{tabular}{|c|c|c|c|c|}
\hline \multicolumn{5}{|c|}{ Estonia } \\
\hline Year & Economic Index (I IEv) & Social Index (Isv) & Environmental Index (I $\left.\mathrm{I}_{\mathrm{AV}}\right)$ & ISDI \\
\hline 2003 & $33.33(3)$ & $33.33(3)$ & $33.33(3)$ & 100.00 \\
\hline 2004 & 35.95 & 33.82 & 36.00 & 105.78 \\
\hline 2005 & 39.95 & 33.80 & 41.38 & 115.12 \\
\hline 2006 & 45.88 & 34.21 & 38.60 & 118.69 \\
\hline 2007 & 48.80 & 34.38 & 41.92 & 125.11 \\
\hline 2008 & 50.27 & 38.82 & 38.15 & 127.24 \\
\hline 2009 & 47.32 & 43.45 & 42.45 & 133.21 \\
\hline 2010 & 48.67 & 47.52 & 40.66 & 136.84 \\
\hline 2011 & 58.73 & 42.74 & 40.93 & 142.40 \\
\hline 2012 & 59.26 & 43.79 & 43.54 & 146.59 \\
\hline 2013 & 56.53 & 44.98 & 44.14 & 145.65 \\
\hline 2014 & 56.31 & 42.90 & 46.14 & 145.34 \\
\hline 2015 & 58.11 & 46.24 & 48.87 & 153.22 \\
\hline 2016 & 57.66 & 46.60 & 48.03 & 152.29 \\
\hline 2017 & 60.75 & 47.64 & 49.61 & 157.99 \\
\hline
\end{tabular}

\section{Appendix 4}

LINEST function results of Lithuania (compiled by authors)

\begin{tabular}{|c|c|c|c|}
\hline \multicolumn{4}{|c|}{ Lithuania } \\
\hline 0.037350 & 0.009479 & 0.001762 & 71.052396 \\
\hline 0.005301 & 0.007720 & 0.002085 & 9.649073 \\
\hline 0.958649 & 5.975143 & \#N/A N/A \\
\hline 85.004166 & 11.000000 & \#N/A & \#N/A \\
\hline 9104.540862 & 392.725651 & \#N/A N/A \\
\hline
\end{tabular}

Appendix 5

LINEST function results of Estonia (compiled by authors)

\begin{tabular}{|c|c|c|c|}
\hline \multicolumn{3}{|c|}{ Estonia } \\
\hline 0.002725 & 0.005052 & 0.009837 & 80.376152 \\
\hline 0.003392 & 0.005809 & 0.002357 & 5.524193 \\
\hline 0.949903 & 4.500764 & \#N/A & \#N/A \\
\hline 69.525256 & 11.000000 & \#N/A N/A \\
\hline 4225.093514 & 222.825637 & \#N/A & \#N/A \\
\hline
\end{tabular}

\section{Appendix 6}

LINEST function results of Latvia (compiled by authors)

\begin{tabular}{|c|c|c|c|}
\hline \multicolumn{3}{|c|}{ Latvia } \\
\hline 0.011944 & 0.019948 & 0.004028 & 86.332798 \\
\hline 0.003626 & 0.006496 & 0.001368 & 4.799278 \\
\hline 0.964243 & 3.450251 & \#N/A & \#N/A \\
\hline 98.877177 & 11.000000 & \#N/A N/A \\
\hline 3531.169537 & 130.946514 & \#N/A & \#N/A \\
\hline
\end{tabular}

